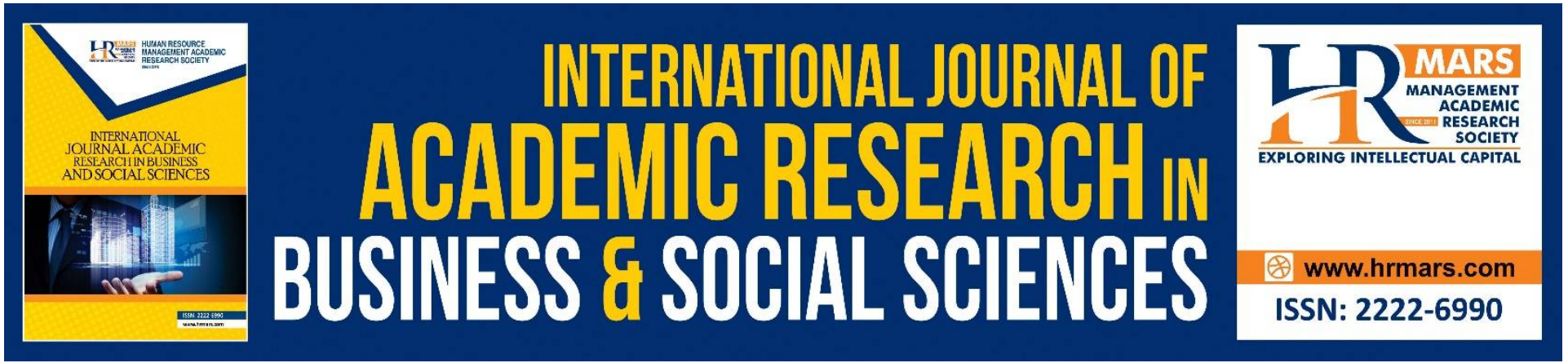

\title{
Homebuyers Superstitious Belief: Feng Shui and Housing Property
}

Mohammad Mujaheed Hassan, Nobaya Ahmad, Ahmad Hariza Hashim

To Link this Article: http://dx.doi.org/10.6007/IJARBSS/v11-i7/10297 DOl:10.6007/JJARBSS/v11-i7/10297

Received: 16 M ay 2021, Revised: 19 June 2021, Accepted: 27 July 2021

Published Online: 15 July 2021

In-Text Citation: (Hassan et al., 2021)

To Cite this Article: Hassan, M. M., Ahmad, N., \& Hashim, A. H. (2021). Homebuyers Superstitious Belief: Feng Shui and Housing Property. International Journal of Academic Research in Business and Social Sciences, 11(7), 444-462.

\section{Copyright: $\odot 2021$ The Author(s)}

Published by Human Resource Management Academic Research Society (www.hrmars.com)

This article is published under the Creative Commons Attribution (CC BY 4.0) license. Anyone may reproduce, distribute, translate and create derivative works of this article (for both commercial and non-commercial purposes), subject to full attribution to the original publication and authors. The full terms of this license may be seen at: http://creativecommons.org/licences/by/4.0/legalcode

Vol. 11, No. 7, 2021, Pg. 444 - 462

http:// hrmars.com/ index.php/ pages/ detail/ IJARBSS

JOURNAL HOMEPAGE

Full Terms \& Conditions of access and use can be found at http://hrmars.com/index.php/pages/detail/publication-ethics 


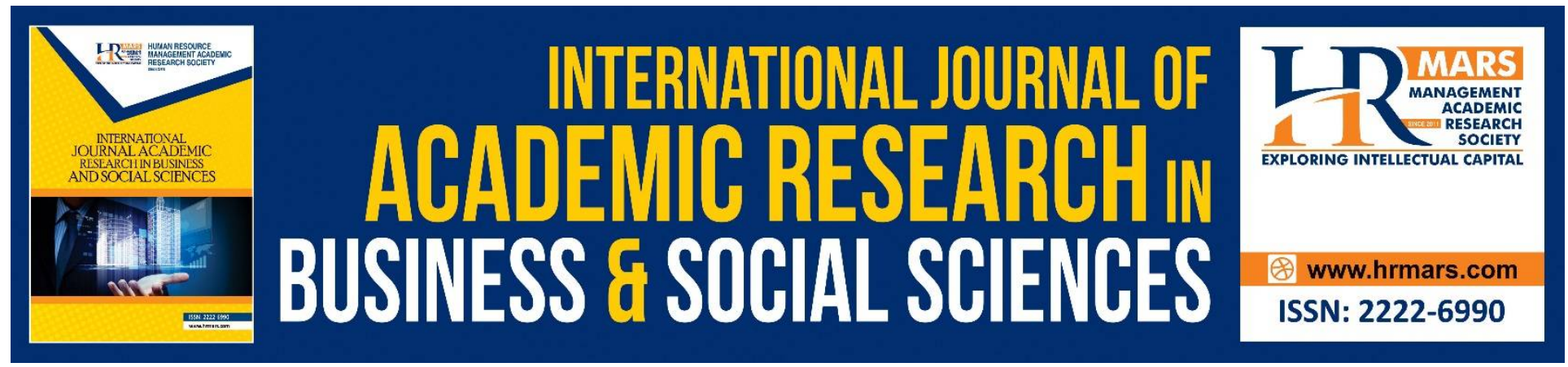

\title{
Homebuyers Superstitious Belief: Feng Shui and Housing Property
}

\author{
Mohammad Mujaheed Hassan ${ }^{1}$, Nobaya Ahmad², Ahmad \\ Hariza Hashim ${ }^{3}$ \\ 1,2,3Faculty of Human Ecology, Universiti Putra M alaysia, M alaysia \\ 1Email: mujaheed@upm.edu.my
}

\begin{abstract}
This article aims to explore the superstitious belief in selecting housing property in M alaysia. Various types of superstitions have been passed down through the ages and remain until today. Based on the instrumental perspective of Feng Shui, prospective buyers instill a belief that success and wealth are influenced by Feng Shui arrangements. Whether Feng Shui is associated with property purchase is a question. Overall, these principles are instilled in the minds of an intuitive Feng Shui believer and implemented in a property purchase. Furthermore, M alaysians are involved in various taboos, folklores, and taboos besides Feng Shui when deciding on property purchase. While some investors make a vow by it as to not make any proceedings before the consultation with their expert, other investors perceive the myths as merely nonsense and old wives' tales. This study are expected to provide guidance to property stakeholders (developers, real estate agencies, architects, local authorities) in their future development projects. For homebuyers, this study serves as a property Feng Shui checklist for home selection and investment.
\end{abstract}

Keywords: superstition, belief, housing property, Feng Shui

\section{Introduction}

The pronunciation for Feng Shui is "Fung Shway", while its literal meaning is "wind and water". Feng Shui plays a role in the decision regarding the building construction, architectural characteristics, where it is located, including furniture design, position, colours, decoration plan, the placement of plantings, paths, and other exterior attributes. With the development of an enhanced atmosphere, Feng Shui is known for its improvements in family communication, restoration of employee teamwork, and an increase in in-store sales. The basic principles of Feng Shui reflect nature in the same way as Taoism. Known in the Asian culture as Tao, it is defined as "the way".

Feng Shui is an abstract art originating from architecture, which is slightly known by an architect in a conscious state or vice versa. Feng Shui is not a ritual requiring irregular positioning of items, it is an art of creating harmony between the home and nature. 
Furthermore, Feng Shui is knowledge regarding the utilisation of energy and space around individuals to improve health (Bhatt, 2018).

Several concrete elements of Feng Shui include proper airflow at home, ventilation, natural lighting, and properly landscaped lands, which are appreciated by many people. It is also a Chinese metaphysical science, which enables one to live in harmonious relationship with the surrounding environment and cosmic energy of the Earth. This practice also focuses on achieving a balance between positive and negative energies and the improvement in individuals' luck by manipulating the surrounding of the places where they spend most of their time.

Feng Shui is a system of laws, which is perceived to control spatial arrangement and alignment of the energy flow (qi), including the positive and negative impacts associated with the development of buildings. Property hunting with Feng Shui within the mind prompts the homeowner to study the impacts of property, such as facing direction, internal layout, and the surrounding area. With proper implementation of Feng Shui, its concepts could be used essentially to improve luck in the forms of career, wealth, relationship, health, and travel.

Superstitious beliefs still play a role in the housing purchase decision, including the actions and behaviour of the younger generation due to the inheritance of beliefs from one generation to another (Hui, Wai, and M ei, 2019). Provided that Chinese superstitious beliefs have a significant effect on house prices (Fortin, Hill, and Huang, 2014), properties with 'good' Feng Shui would have a higher market price, while the properties with 'bad' Feng Shui would be sold below market price. Furthermore, many buildings and houses are built around Feng Shui principles, such as having a river in front and a mountain behind. There are various reasons to the practices in Chinese ethnics despite the absence of scientific reasons to prove that positive or negative events occur when occupied houses are associated with superstitious beliefs (Hui, Wai, and M ei, 2019).

\section{The Essential Concepts of Feng Shui in Selecting Property}

Feng Shui is a system of laws, which are perceived to control the spatial placement and alignment related to the flow of energy (qi), including the positive and negative impacts in the development of buildings. To ensure a successful application of Feng Shui whether, for house or office, the Bagua or the Feng Shui energy map would normally be used to calculate and determine the ideal energy space. There are two different ways of defining the Feng Shui Bagua, namely the classical school and the Black Hat Sect, Black Sect Tantric Buddhism (BTB), or Western school.

Bagua is among the primary devices of Feng Shui for the analysis of the Feng Shui energy within any areas. The Chinese translation defines Bagua as "eight areas" as shown in Figure 1. In defining the classical or traditional Feng Shui Bagua of a house or office, the compass reading takes place from the front door of the house or office. 


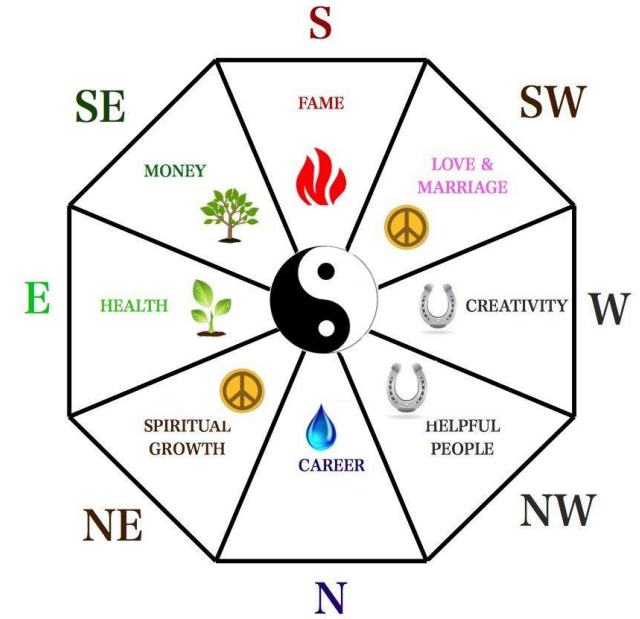

Figure 1: The Classic Bagua (Source: The Spruce)

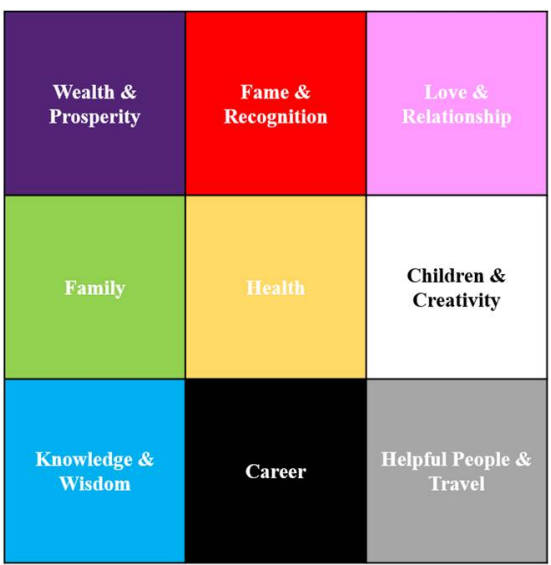

Figure 2: The Black Sect Tantric Buddhism (BTB) or Western Bagua

The BTB Bagua is a nine-grid square as shown in Figure 2 developed from the Classical Feng Shui Lo Shu Square, which is also known as the magic square. The BTB Bagua is divided into three evenly spaced rows across and three columns down to form a nine-square grid. The Bagua represents the flow of chi through the home or workspace. Feng Shui Bagua is used in the BTB to define each sector and provide understanding to the believer regarding the energy governing that area (see Table 1 on the use of BTB to define each sector).

Table 1: The descriptions summary of BTB

\begin{tabular}{|c|c|c|c|c|c|c|c|}
\hline $\begin{array}{l}8 \\
8 \\
8 \\
8 \\
8 \\
8 \\
0 \\
0 \\
1\end{array}$ & 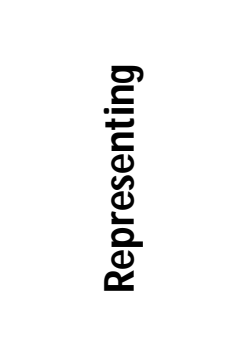 & $\frac{8}{\frac{8}{6}}$ & $\frac{1}{9}$ & $\begin{array}{l}5 \\
8 \\
8\end{array}$ & $\frac{8}{8}$ & 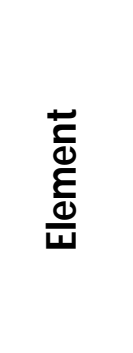 & 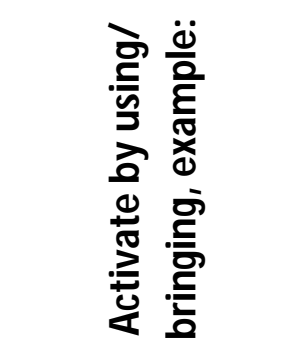 \\
\hline Zhen & $\begin{array}{l}\text { Family, new } \\
\text { beginnings }\end{array}$ & $\begin{array}{l}\text { Columnar, } \\
\text { rectangular }\end{array}$ & Green & Spring & 4 & $\begin{array}{l}\text { Yang } \\
\text { Wood }\end{array}$ & $\begin{array}{l}\text { Bringing living } \\
\text { green plants for } \\
\text { more wood } \\
\text { energy }\end{array}$ \\
\hline Xun & $\begin{array}{l}\text { Wealth, } \\
\text { prosperity, } \\
\text { abundance }\end{array}$ & $\begin{array}{l}\text { Columnar, } \\
\text { rectangular }\end{array}$ & Purple & Spring & 5 & $\begin{array}{l}\text { Yin } \\
\text { Wood }\end{array}$ & $\begin{array}{l}\text { Using amethyst } \\
\text { crystals }\end{array}$ \\
\hline Tai Qi & $\begin{array}{l}\text { Health, } \\
\text { wellness }\end{array}$ & Flat, square & $\begin{array}{l}\text { Brown, } \\
\text { orange, } \\
\text { yellow }\end{array}$ & $\begin{array}{l}\text { Transitions } \\
\text { between } \\
\text { the season }\end{array}$ & 5 & Earth & $\begin{array}{l}\text { Square earth } \\
\text { toned rug in the } \\
\text { center of the } \\
\text { house }\end{array}$ \\
\hline
\end{tabular}


Internat lonal Journal of academlc resear ch In Buslnessand soclal sclences Vol. 11, No. 7, 2021, E-ISSN: 2222-6990 @ 2021 HRM ARS

\begin{tabular}{|c|c|c|c|c|c|c|c|}
\hline Qian & $\begin{array}{l}\text { Helpful } \\
\text { people, } \\
\text { travel }\end{array}$ & $\begin{array}{l}\text { Circular, } \\
\text { spherical }\end{array}$ & Gray & Autumn & 6 & $\begin{array}{l}\text { Yang } \\
\text { Metal }\end{array}$ & $\begin{array}{l}\text { The sound of } \\
\text { metal bells or } \\
\text { chimes to } \\
\text { vibrate Qian } \\
\text { position of the } \\
\text { house }\end{array}$ \\
\hline Dui & $\begin{array}{l}\text { Children, } \\
\text { creativity }\end{array}$ & $\begin{array}{l}\text { Circular, } \\
\text { spherical }\end{array}$ & White & Autumn & 7 & $\begin{array}{l}\text { Yin } \\
\text { Metal }\end{array}$ & $\begin{array}{l}\text { Fragrant fresh } \\
\text { cut white } \\
\text { flowers }\end{array}$ \\
\hline Gen & $\begin{array}{l}\text { Knowledge, } \\
\text { wisdom }\end{array}$ & Flat, square & $\begin{array}{l}\text { Dark } \\
\text { blue }\end{array}$ & $\begin{array}{l}\text { Transitions } \\
\text { between } \\
\text { season }\end{array}$ & 8 & $\begin{array}{l}\text { Yang } \\
\text { Earth }\end{array}$ & $\begin{array}{l}\text { Using a heavy } \\
\text { rock from the } \\
\text { earth to stabilize } \\
\text { Gen position }\end{array}$ \\
\hline Li & $\begin{array}{l}\text { Fame, } \\
\text { recognition }\end{array}$ & $\begin{array}{l}\text { Triangle, } \\
\text { pointy }\end{array}$ & Red & Summer & 9 & Fire & $\begin{array}{l}\text { Light fixtures or } \\
\text { candles to bring } \\
\text { in more fire } \\
\text { element }\end{array}$ \\
\hline Kan & Career & Wavy, curvy & Black & Winter & 1 & Water & $\begin{array}{l}\text { Images and } \\
\text { sounds of water } \\
\text { to inviting water } \\
\text { energy }\end{array}$ \\
\hline Kun & $\begin{array}{l}\text { Love, } \\
\text { relationship }\end{array}$ & Flat, square & Pink & $\begin{array}{l}\text { Transitions } \\
\text { between } \\
\text { the } \\
\text { seasons }\end{array}$ & 2 & $\begin{array}{l}\text { Yin } \\
\text { Earth }\end{array}$ & $\begin{array}{l}\text { A pair of } \\
\text { tumbled rose } \\
\text { quartz to work } \\
\text { with Kun } \\
\text { position }\end{array}$ \\
\hline
\end{tabular}

The basic principles of Feng Shui include the commanding position, Bagua, and five components, which could be incorporated in any building and decoration designs besides Chinese designs. These components are the interrelated stages of life functioning simultaneously to develop a complete system. Among the principles of Feng Shui is the principle of five components, namely wood, fire, earth, metal, and water. Interaction takes place between these components in specific methods commonly identified as the productive and destructive cycles. These components also originate from the Taoist tradition. The practice of Feng Shui has a common role in balancing the five aspects of life and home areas or Bagua. Notably, each Feng Shui element is indicated through a particular colour, which is the most efficient method of using the five-component principle to enhance the balance in the house. Table 2 shows the descriptions summary of five elements namely as earth, metal, water, wood and fire. 
Table 2: The descriptions summary of Five Elements

\begin{tabular}{|c|c|c|c|c|c|c|c|}
\hline 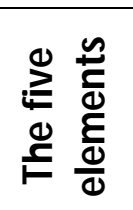 & $\begin{array}{l}\frac{y}{2} \\
\frac{0}{2} \\
\frac{2}{0}\end{array}$ & $\frac{8}{8}$ & $\frac{8}{6}$ & $\frac{n}{9}$ & $\begin{array}{l}8 \\
\$ \\
\$\end{array}$ & 8 & 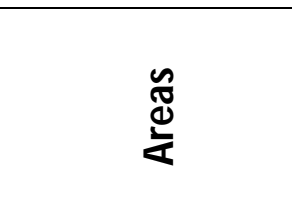 \\
\hline Earth & $\begin{array}{l}\text { North } \\
\text { East/ } \\
\text { South } \\
\text { West } \\
\text { Center }\end{array}$ & $\begin{array}{l}\text { Grounded, } \\
\text { self-care, } \\
\text { stable }\end{array}$ & Flat & $\begin{array}{l}\text { Brown, } \\
\text { orange, } \\
\text { yellow }\end{array}$ & $\begin{array}{l}\text { Transitions } \\
\text { between } \\
\text { the season }\end{array}$ & Touch & $\begin{array}{l}\text { Tai Qi (health, } \\
\text { wellness), Gen } \\
\text { (knowledge, } \\
\text { wisdom) \& Kun } \\
\text { (love, } \\
\text { relationship) }\end{array}$ \\
\hline Metal & $\begin{array}{l}\text { West/ } \\
\text { North } \\
\text { West }\end{array}$ & $\begin{array}{l}\text { Efficient, } \\
\text { precise, } \\
\text { beauty }\end{array}$ & $\begin{array}{l}\text { Circular, } \\
\text { spherical }\end{array}$ & $\begin{array}{l}\text { White, } \\
\text { gray }\end{array}$ & Autumn & Smell & $\begin{array}{l}\text { Qian (helpful } \\
\text { people, travel) \& } \\
\text { Dui (children, } \\
\text { creativity) }\end{array}$ \\
\hline Water & North & $\begin{array}{l}\text { Wisdom, } \\
\text { serenity }\end{array}$ & $\begin{array}{l}\text { Wavy, } \\
\text { curvy }\end{array}$ & Black & Winter & Hearing & Kan (career) \\
\hline Wood & $\begin{array}{l}\text { East/South } \\
\text { East }\end{array}$ & $\begin{array}{l}\text { Expansive, } \\
\text { vitality }\end{array}$ & $\begin{array}{l}\text { Columnar, } \\
\text { rectangular }\end{array}$ & $\begin{array}{l}\text { Green, } \\
\text { purple }\end{array}$ & Spring & Sight & $\begin{array}{l}\text { Zhen (family, } \\
\text { new beginnings) } \\
\& \text { Xun (wealth, } \\
\text { prosperity, } \\
\text { abundance) }\end{array}$ \\
\hline Fire & South & $\begin{array}{l}\text { Passion, } \\
\text { illuminating }\end{array}$ & $\begin{array}{l}\text { Triangle, } \\
\text { pointy }\end{array}$ & Red & Summer & Taste & $\begin{array}{l}\text { Li (fame, } \\
\text { recognition) }\end{array}$ \\
\hline
\end{tabular}

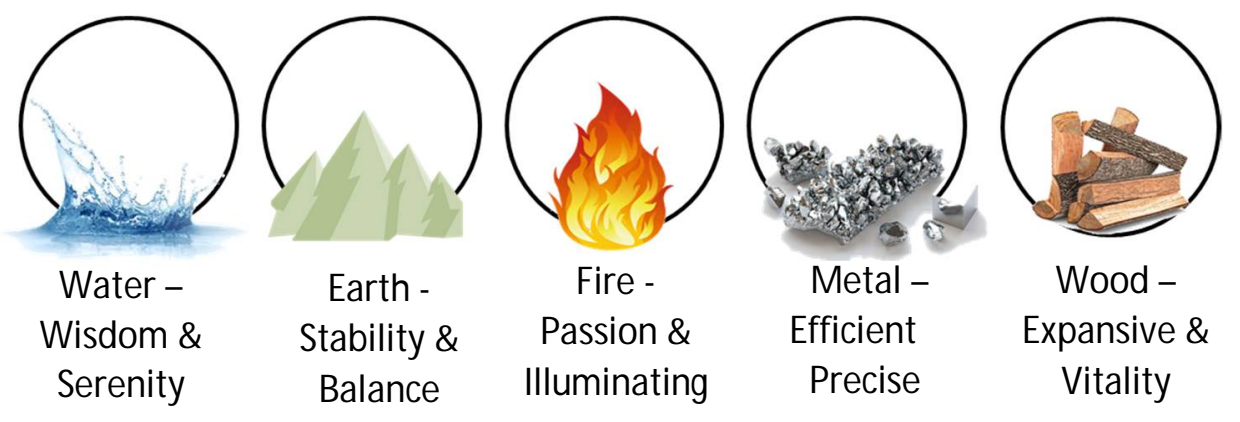

Figure 3: Five elements

Although the knowledge of methods to employ colours enhance and stabilise the energy within the house is a complex Feng Shui subject, the fundamentals of it remain. The correct positioning of Feng Shui colours is identified by the Bagua or the Feng Shui energy map of the space. To include the components in life and home, the point of focus of the energy should be emphasised. Similar to the Bagua, individuals can select one to three aspects of their life for improvement and enhance their energy by incorporating the recommended colours or shapes in the room. 
To achieve a quality Feng Shui, property buyers should be aware of the destination, neighbourhood, and lot positioning (Kong and Chiong, 2006; Tchi, 2013). Notably, the analysis of the terrain, placement, and direction of the property is crucial to secure the good residence and comfort degree for the residents, which would influence their health and wealth (Chu, $\mathrm{Hsu}$, and Hsieh, 2017). The energy accompanied by hills as the surroundings and supported by mountains would transmit positive energy (Wu, Yau, and Lu, 2012). This type of energy comprises an open space in front of the house, where a lake or a river is also present ( $\mathrm{Xu}$, 1997).

However, street or road of any forms or categories could bring negative energy to the household when the road is placed in an upper position than the property. This situation does not regard the narrow path, main road or highway, trunk road, country road, or main road (Fong, 2007). Furthermore, Fong (2007) stated that a house placed at the cross junction or a T-junction is not constantly an ideal place to reside in. Several individuals strongly believe that a lucky number could bring luck in their lives (Too, 1997). Specifically, number ' 4 ' is considered an unfortunate number as its pronunciation is similar to the pronunciation for the word 'death' in Cantonese (Rehm, Chen, and Filippova, 2018). Buyers aim to prevent the purchase of houses with addresses containing unfortunate numbers despite their claim of not believing Feng Shui. This action is due to their worries about the possibility for the property to be resold (Boyer, 1995). Following are the regular activities and faith in Feng Shui.

\section{Numbers}

Although it is clear that negotiating property prices deals with numbers, in a society where superstitions and beliefs still play a big part in individuals' everyday lives, house numbers could seal or break a deal. In many Asian cultures, particularly China, Malaysia, Korea, and Singapore, numerology is a crucial process.

Chinese in Malaysia show aversions toward certain numbers. Specifically, within the range of 0 to 9 , numbers ' 2 ', ' 3 ', ' 6 ', ' 8 ', and ' 9 ' have favourable indications, while numbers ' 4 ' and ' 5 ' indicate negative luck upon the pronunciation in the Cantonese dialect (Chong and $\mathrm{Du}, 2008$ ). Furthermore, as a result of the significance of numbers ' 8 ' and ' 4 ', there was a universal agreement within the Chinese community that ' 8 ' carries positive luck, while ' 4 ' carries negative luck (Wong, Abdullah, and Lim, 2017). The number ' 8 ' is also perceived to carry a positive indication due to its similar pronunciation to the word 'prosperous' in Cantonese. This similarity leads to the association of this number with 'wealth'. However, number ' 4 ' might have the highest association with superstition. The Cantonese pronunciation of this number is "Sei", which could also indicate 'death' when pronounced in a slightly different manner (Rehm, Chen and Filippova, 2018).

The presence of a property or floor represented by the number ' 4 ' is rare, while numbers '14' and '24' are regarded as ineffective in comparison to ' 4 ' (Yau, 2015). Furthermore, the pronunciation of '14' is "Sap Sei", which is near to "Sat Sei" and interpreted as "Sure to Die", while the pronunciation of '24' as "Yi Sap Sei" is near to the pronunciation for the word indicating "Easy to Die". Figure 4 shows Lift numbering in M alaysia 4 is frequently switched to $3 \mathrm{~A}$, as seen in the building floors and elevator buttons (Level $3>3 \mathrm{~A}>5$ ).

The Malay community in Malaysia conveys a distinguished story related to ' 4 ' with the pronunciation of "Empat". This pronunciation is similar to the word "Dapat", which indicates 
reception. Several communities convey tales that the shape of this number resembles a person sitting cross-legged and appearing relaxed. Notably, the most infamous number internationally is the unlucky number ' 13 ', which is to the point that developers do not place the '13' label in a high-rise block. Furthermore, homeowners place a house name instead of this number. People also prevent buying houses containing unlucky numbers in the address despite their claim of not being the Feng Shui believers. They have a concern regarding the resale possibility of the property (Boyer, 1995).

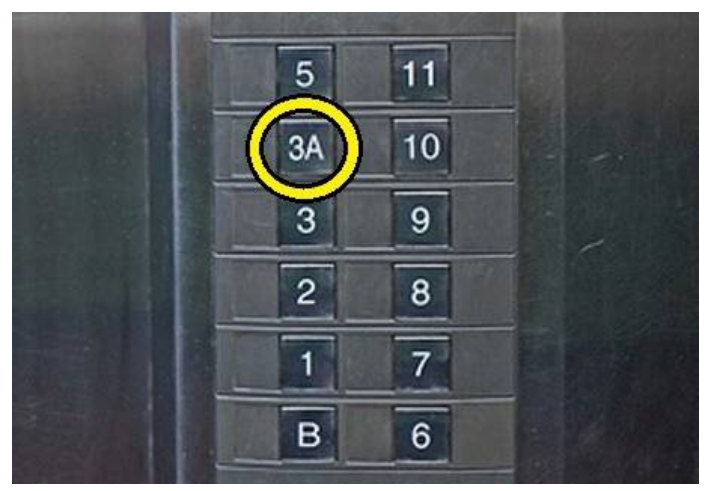

Figure 4: Lift numbering in Malaysia

\section{The History}

Provided that history exists in all properties, finding the type of history is recommended. When a property is left empty for a long time until there is an eerie air around it, an unnatural death is assumed to have happened in it, including suicide or murder. Most Malaysians believe that the spirit of the dead would remain in the community. Certain residential units are developed from the remains of religious places and old hospitals. However, this development is not allowed for the majority of the communities as these properties are perceived to be full of spirits. Additionally, it is believed by Chinese people that the elimination of spirits required the demolition of the building. Exposure to the sunlight for a minimum of 49 days is required for the care site before the building development.

\section{The View}

The appearance of cemeteries around the house may be unwelcoming. The majority of local communities do not prefer residing close to cemeteries, hospitals, and religious sites due to the apprehension towards "Ying Qi" or negative energy radiating to the residents nearby as shown in Figure 5 and 6 , which result in health issues, troubles in sleeping, and negative luck (Bhatt, 2018).

The Chinese elderlies have warned against residing in high-rise buildings, which are placed facing the curved elevated highways as they are identical to a sickle. A sickle has negative indications regarding the house owner's well-being and fortune. Specifically, it could lead to noise pollution, which affects one's concentration and sleep, and interferes with personal health, relationships, and well-being (Bhatt, 2018). 


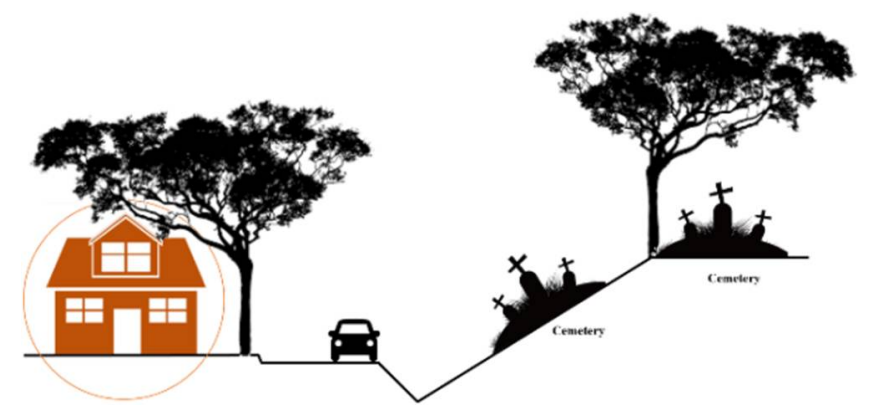

Figure 5: The house view close to cemeteries

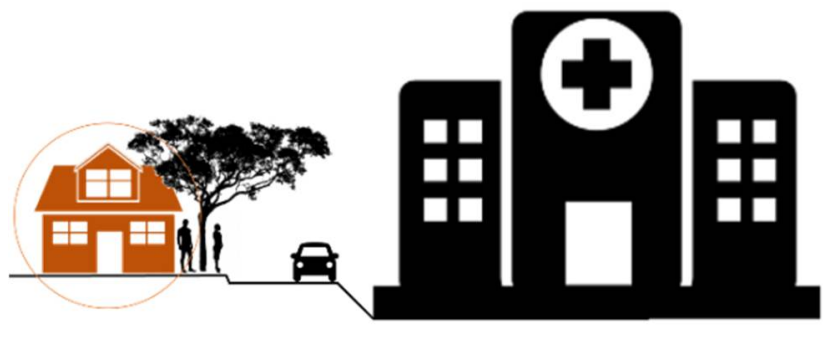

Figure 6: The house view close to the hospital

The Indian community focuses on properties, which are facing the water bodies in the correct position. Based on the traditional Hindu system of architecture known as 'Vastu Shastra', water is a major energy generator. It could produce positive and negative energies according to its location.

\section{The Direction}

The Indian community does not prefer to have the main doors positioned Southwest as this direction is believed to allow the entry of the devil. However, the Chinese community prevents having their properties positioned at the location of the sunset (East) or sunrise (West) as shown in Figure 7. Furthermore, preventing direct sunlight could contribute to lower indoor temperature.

The M uslims in M alaysia focuses on the placement of Qibla when choosing properties. Qibla is the guide used by Muslims' prayers based on the placement of Kaaba in Mecca. Furthermore, the bathroom and shower should be parallel to the position of the Qibla when performing the Wudhu (ablution), while bedrooms should be positioned perpendicular to the Qibla. In terms of the position of the bed, it should enable people to sleep on the right side in the Qibla direction. Similarly, the desks should also be in the direction of Qibla.

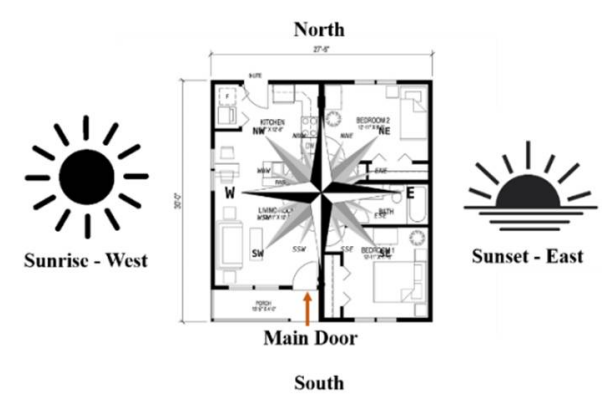

Figure 7: The Chinese people preventing the main door from being positioned towards the East or West. The South is the ideal direction for wealth 


\section{Locations}

In the past, people are highly reliant on Chinese geomancy knowledge and experience in the selection of an ideal location to reside in (He, 1995). To obtain an ideal Feng Shui, knowledge regarding the destination and lot position is important for the property buyer (Kong and Chiong, 2006; Tchi, 2013). Therefore, it is crucial to analyse the terrain, position, and direction of the property to achieve the standard of residence and comfort, which would influence the well-being and wealth of the tenants (Chu, Hsu, and Hsieh, 2017).

A house positioned at a cross junction or a T-junction as shown in Figure 8 is not an ideal place to live in (Fong, 2007). A home located at a T-Junction should be avoided as the cars moving at high speed would directly spread energy to the house. This type of energy is called "Sha-Qi" or bad energy caused by the T-Junctions. From a practical perspective, this selection is made to avoid the direct emission of car headlights to the house every night upon its presence at the junction as it could bring annoyance to the occupants. However, the flexibility of Feng Shui could be seen from the ability of the house owner to relocate the main gate to the side when the house is positioned in the direction of a T-junction. A solid wall could also be placed at the place facing the T-junction.
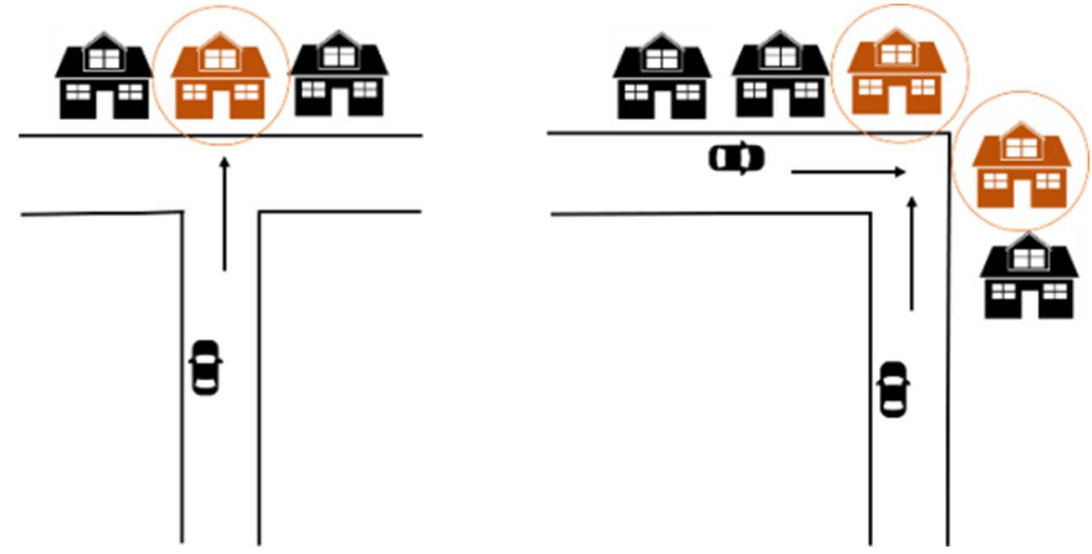

Figure 8: A T-junction house is considered bad Feng Shui and unprotected

According to folk tales, owning a house positioned under the road level is not encouraged as it would facilitate the flow of negative luck. Street or road in any shape or type, such as a narrow path, country road, trunk road, main road or highway, is believed to bring negativity to the household when the road is positioned higher than the property (Fong, 2007).

A concept similar to the aforementioned concept is the taboo of positioning the house under the road level. To illustrate, the rain occurring at the top of the mountain indicates fortune in Chinese beliefs. It is then followed by the flow of water from the mountain to the valleys. Accordingly, all individuals around the area would obtain the fortune, leaving the remnants to those residing at the valley. From a practical perspective, house positioned under the road level and the most bottom part of the valley has a higher susceptibility to flooding especially during torrential rains. Therefore, it is important to ensure that the house is protected from flooding (Tam, Tso, and Lam, 1999).

Any road, river, or canal at the back of the house should be avoided. Similarly, the flow of water in front of the house is risky. Essentially, water indicates fortune in the Chinese culture, which explains the importance of the positioning of any water features outdoor and 
indoor. The flow of water should be from the right to the left along the front, while the traffic flow on the road should be from the right to the left.

The ideal location of the home should contribute to energy through hills as the surroundings, mountains ( $\mathrm{Wu}, \mathrm{Yau}$, and Lu, 2012), and open space in front of the house with water from either a lake or river flowing in it (Xu, 1997).
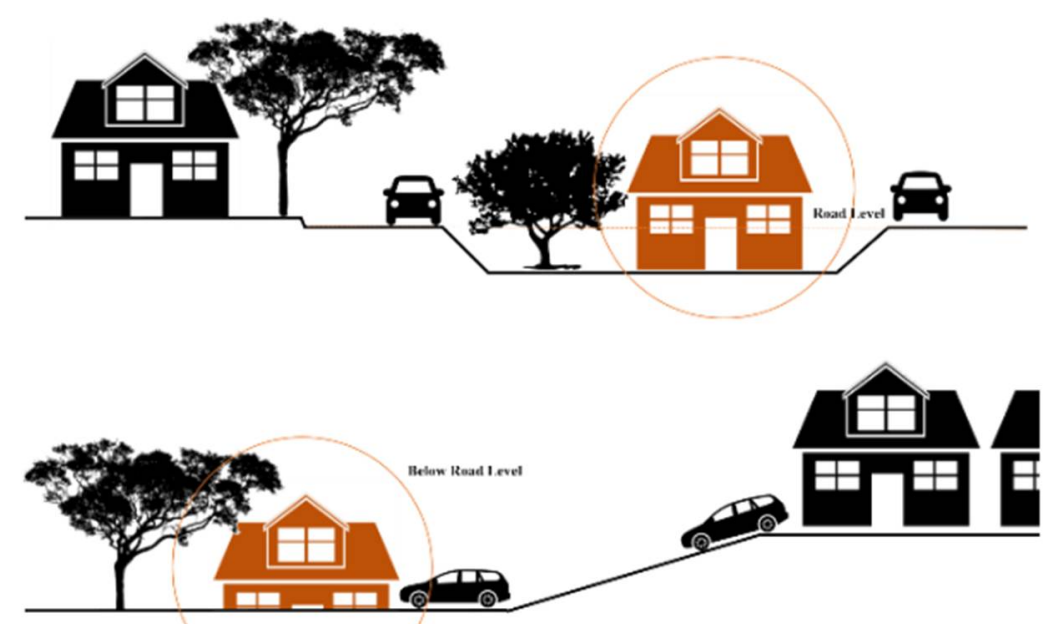

\section{Neighbourhood}

Figure 9: The house under the road level

The neighbourhood is a good indication of the type of energy flowing in the area. When a high number of "For Sale" signs and empty houses are in sight, it indicates a high amount of used or negative energy floating around the areas. Therefore, it is important to choose a lively and vibrant area where kids could play and residents could perform exercises. Overall, the presence of numerous activities is a good indicator of positive energy.

\section{The Dwelling Features}

\section{The Main Door}

The most crucial areas during property purchase by the property investors are the quality and position of the main door since they would not be residing in the unit for an extended duration. The main door of the house is crucial due to its function as the primary house entrance. The front door is also the mouth of the house as it allows almost $70 \%$ of the outside energy, which may be either positive or negative. Therefore, it is indicated through superstitions removal of any obstacles in front of the primary door, which could prevent the flow of positive energy (e.g., pillars, pots, and lamps) is important.

The accumulation of positive energy and its long-lastingness is important in a property. Therefore, the view of the kitchen, toilet, or backyard should not be available when the front door is opened. However, when the front door is directly positioned in front of the staircase, the energy would flow to the upper floor, resulting in an empty ground floor. Notably, the flow of a gentle and soft breeze is important, while the strong wind would result in an unstable rush of energy.

Provided that the main door should also be proportional to home, an oversized or excessively small door should not be built. Therefore, the main door should be made slightly 
larger compared to other doors inside the home. According to the belief of most Malaysian communities, bigger primary doors would contribute to more fortune and success. However, the presence of a drain adjacent to the main door should be taken into account to prevent the loss of any wealth.

\section{Floor Plan Layout}

The floor plan should be surveyed as the most auspicious shapes of the floor are square or rectangle. An " $\mathrm{L}$ " shaped house resembles two rectangles as shown in Figure 10, which are mashed together at an angle, while the "missing" sectors would lead to a negative Feng Shui, leading to quarrels and arguments. Provided that the perfect space projects balance and stability, L-shaped house design is not encouraged (Bhatt, 2018). Moreover, any missing corners or cut-outs should be identified due to the inauspicious impacts they may have on certain family members. However, the general guideline regarding the missing corner is absent in this area by a minimum of $33 \%$.

Several areas are lost due to the absence of conduciveness in the architectural form of the house to the traditional Bagua map. As a solution, various cures are made with an attempt to fill the energy, which has inadequate areas of the map. When an area in the Bagua (Feng Shui energy map) of the house is lost, negative energy within the house would form. Given the intricate connection between individual life's standard and state of energy within the house, the lost Bagua area requires maintenance. Notably, the most ideal method of balancing the energy of any lost areas is through the equivalent Feng Shui components.

Bagua extensions refer to the house or apartment vicinities situated at the exterior of the house Bagua. Accordingly, the extensions indicate the areas, which stand out from the home Bagua by a minor extent. In some cases, this situation is caused by architectural aberration, where the developer has provided dwelling, which reaches until the exterior of the Bagua boundary. Although this is not an issue, solutions are needed to reduce the instability of the projecting energy.
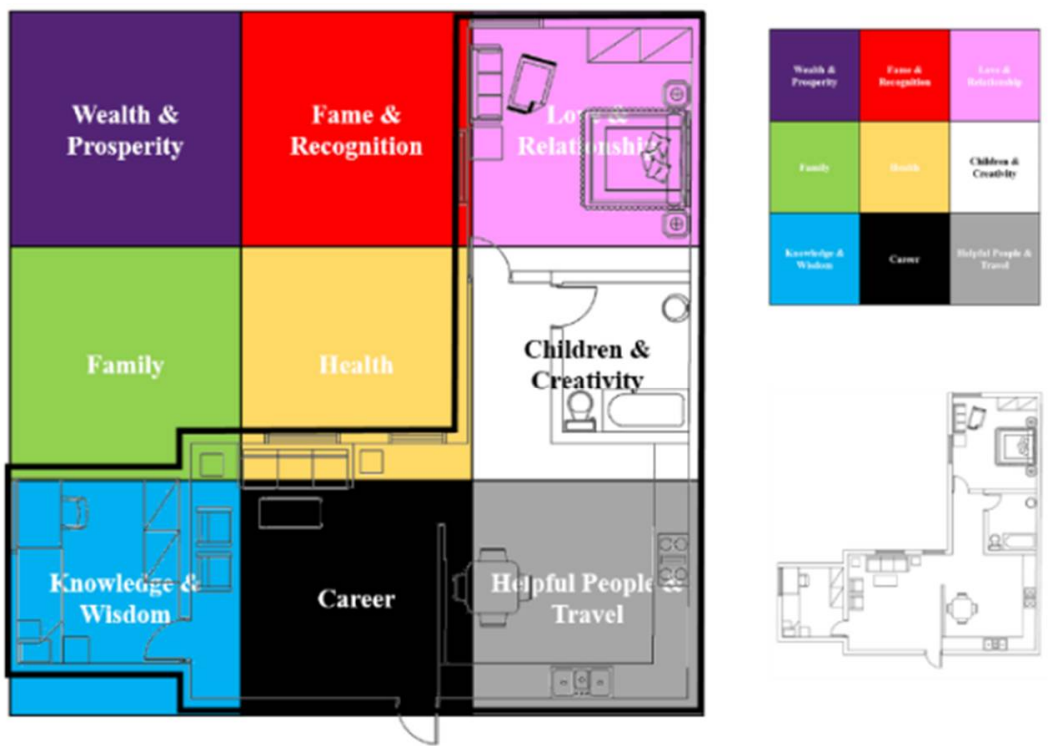

Figure 10: Feng Shui Bagua M ap overlay with an L shape floor plan house showing the missing corners 


\section{Bedroom}

Four key elements are present in a good Feng Shui inside a bedroom. First, neutral or light pastel tone should be selected for the furniture and wall paint, while bright colours, such red or pink should be avoided due to the excessive active "Yang". The bed should never be placed parallel to the bedroom or toilet door. Furthermore, it should not be positioned opposite to a toilet bowl on the other side of the wall, while the toilet or bedroom should not be located beside the bed headboard. When the shifting of bed could not be made, the house tenant should create a barrier between the bed and the door, although it may contribute to illness for the individual who sleeps on the bed.

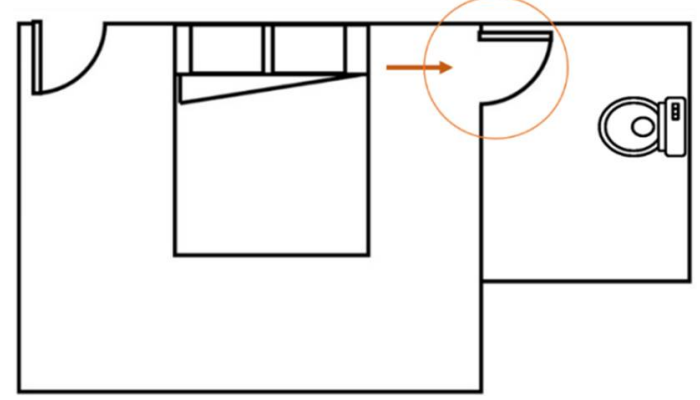

Figure 11: A bed parallel to the toilet door

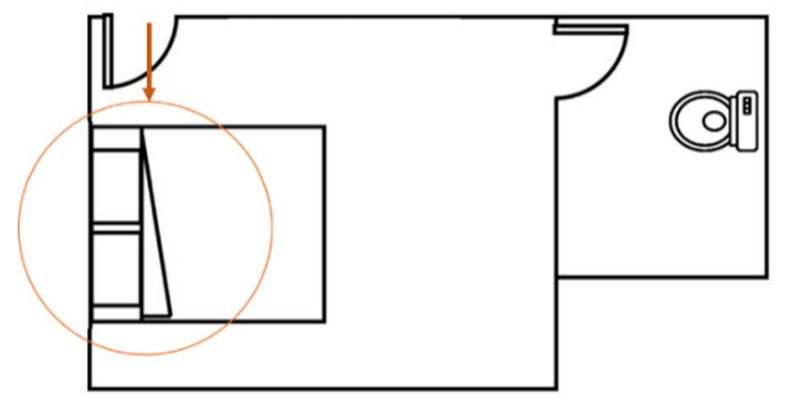

Figure 12: A bed parallel to the bedroom entrance

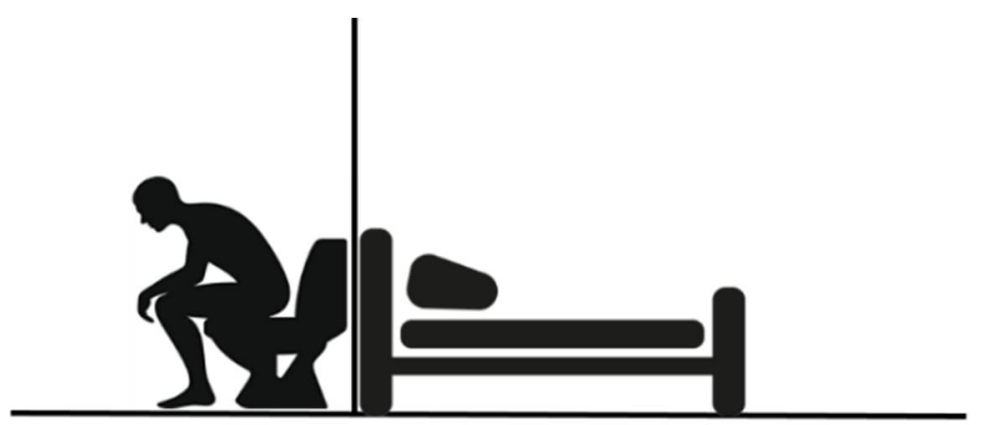

Figure 13: The bed positioned back-to-back with the toilet bowl

Overhead beams above the bed are considered negative energy spots. The energy floating along on the ceiling is blocked by the beam before being emitted downwards to the person who is sleeping below it. The same case goes for the triangle-sloped ceilings underneath the roof. Furthermore, sleeping problems are one of the issues occurring with these features in the bedroom. The absence of beams above the bed would contribute to comfortable sleeping hours. Additionally, the bed should not be situated in the smallest space of the sloping ceiling when an individual is sleeping in an attic. 


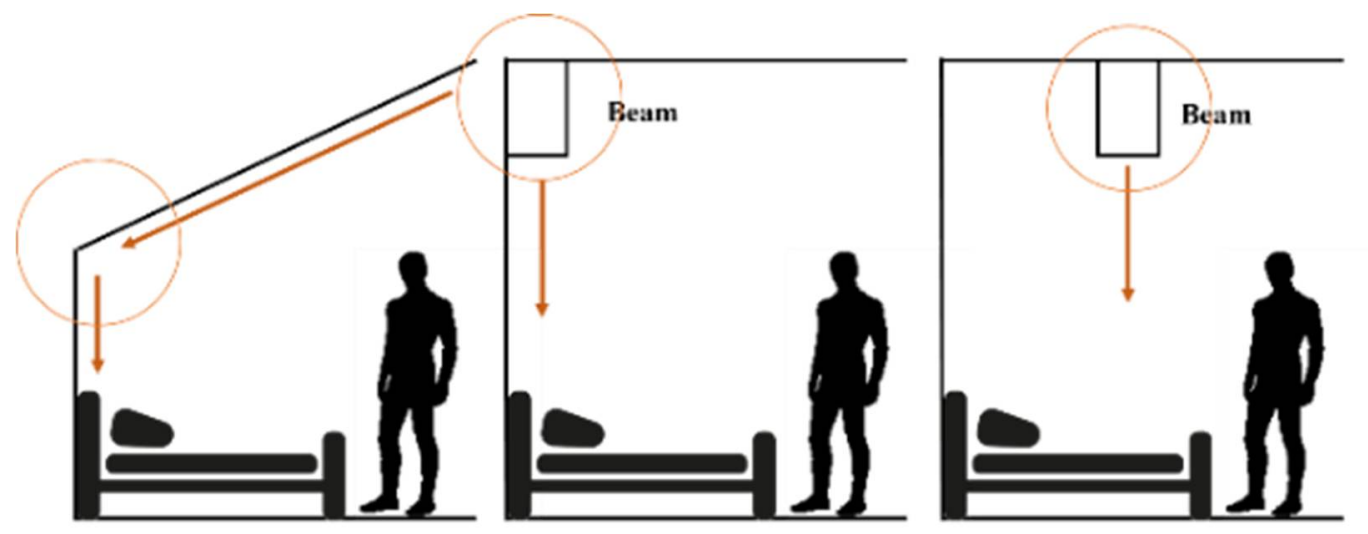

Figure 14: Bed setup

\section{Kitchen}

Provided that the kitchen is also known as the Strong Fire-Element in the Five Transformation Theory, the stove should not be facing the front door, the toilet, or the bedroom. All fire colours (red, orange) as wall paint or cabinet design are not encouraged as they would create more "fire" into the kitchen.
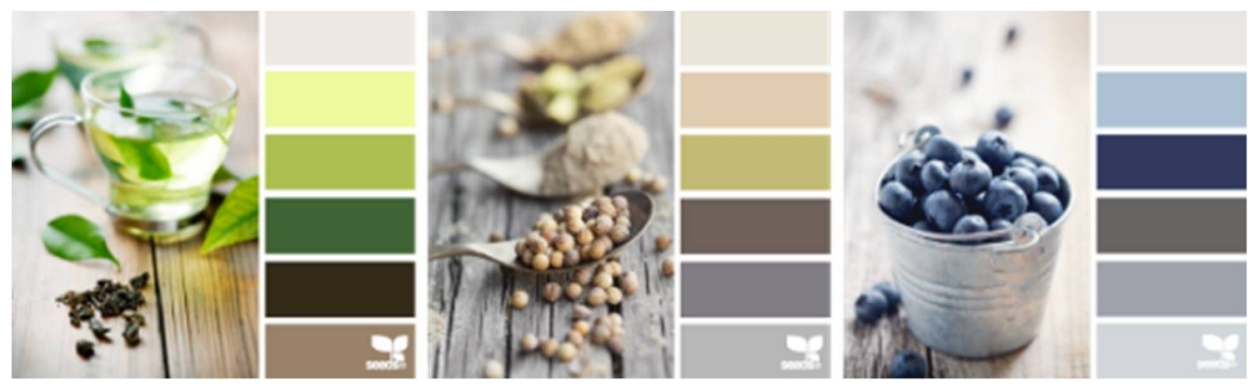

Figure 15: Colour tones suitable for kitchen

The ideal location of a kitchen is the backside of the home instead of its centre or entrance. However, various bad lucks could occur from the absence of reservation. Furthermore, no overhead beams should be present above the stove or a placement right next to the kitchen door.

A kitchen must be positioned at the back of the house within enclosed walls instead of outside of the house. Furthermore, the kitchen stove should be constantly placed under the sink in the kitchen instead of on the same level or facing each other. Even in the case of the latter, the kitchen stove and the sink should be separated by a solid object. M oreover, the stove should not be positioned back-to-back with a toilet bowl on the other side of the wall nor under the bed on the upper floor. Otherwise, the bed should be relocated promptly. Any toilets, particularly a toilet bowl or shower, should not be present on the stove in the upper floor as shown in Figure 16. 

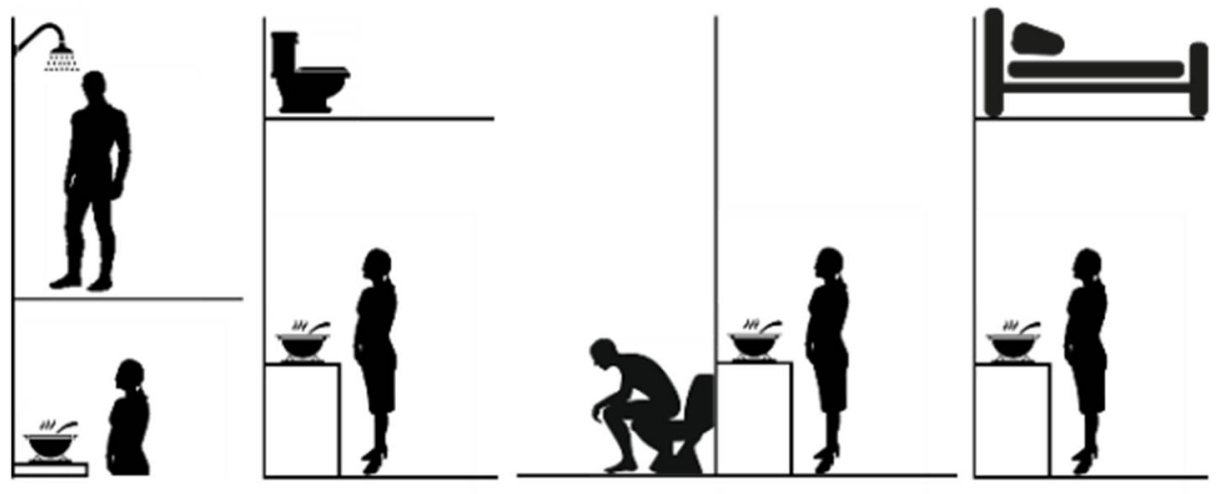

Figure 16: Bed kitchen setup

\section{Bathroom}

The bathroom or toilet should not be located either in the centre of the house or in plain view when the front door is opened. Furthermore, the kitchen and toilet doors should not be facing each other. All the layout flaws could contribute to illness to the residents living in the home. In the case of the bathroom interior, neutral tile colours should be selected, while the mirror/sink is placed either on the left or right side upon entry to the bathroom.

\section{Living Room}

A living room with a proper design brings balance and harmony to the whole family. The shape of the room should be either square or rectangle with a placement at the centre of the home. Provided that a bright environment is preferable for a living room, windows should also be made to allow the emission of sunlight. In contrast, a dark area would diminish good energy within the room. Therefore, any overhanging beams should be avoided as they are considered inauspicious.

\section{Past Research on Superstitious Belief in Malaysia Housing Purchase Decision}

Table 3 shows a summary review from past research that related to superstitious belief in Malaysia housing purchase decision.

Table 3: Summary review on previous research

\section{Previous research Authors Result}

The Effect of Superstitious Hui, M.K., Wai, WC. Hui et al. found that the overall effect of Belief on Property Purchase W., Mei, N. S. superstitious beliefs on purchasing intention Intention (2019) was not significant due to the weak impact of the R2 on purchasing intention. Therefore, it could be concluded that superstitious beliefs still play a role in house purchasing intention. Superstitious beliefs remain within the younger generation, which was the largest sampling group in this study survey. It was found that superstitious belief still affected this generation's action 
and behaviour as it is passed down from one generation to another.

Influence of Feng Shui Mal Kong Sia, A survey was performed in Kuala Lumpur Factors on House Buying Vivien Wong Chin and Sandakan, with Feng Shui ranking third Intention of among Yew, and Chee Lam as a significant element in house purchase. Malaysian Chinese Siew, $2018 \quad$ The respondents stated their preference for houses with a strong wooden front door, regular-shaped and well-lit living room, including a sea view. Meanwhile, a house built in front of the cemetery, a land with a non-uniform shape, and a smaller primary door and bedroom situated at the end of the corridor were identified as the most adverse elements of the environment, internal and external layout, and interior arrangement, respectively. It was indicated by the independent samples t-tests and chi-square test of independence that minor differences were present in the perspectives regarding Feng Shui between the participants from Kuala Lumpur and Sandakan although they are different in the geographic terms.

Understanding Factors that Chia, J., Harun, A., Chia et al. (2016) found that superstition Influence House Purchase Intention Among Consumer Mohd Kassim, in Kota Kinabalu: An and Kepal, Noreina, Application of Buyer 2016 Behaviour Model Theory numbers have a significant but weak positive relationship with house purchase intention $(\beta=.136, p<.05)$. However, superstitionghosts had a negative but insignificant relationship with house purchase intention $(\beta=-.942, p>.05)$. The ghosts phenomena did not influence house purchase behaviour as the belief regarding this phenomenon was not present.

Influencing Factors of Salleh, N. A., Zoher, Feng Shui elements were scored with 7 out Property Buyer in Hillside S. A., Mahayuddin, of 7, which was the lowest with a mean score Residential Development S. A., and Abdul, Y., of 3.34 out of 5 Likert Scale. Only $50 \%$ of the 2015 respondents believed in Feng Shui element as one of the factors of their purchase decision. 
The Significance of Feng Shui Liang, C. C., and in House Buying Selection Osmadi, A. , 2015 among M alaysians
Liang et al. stated that unfavourable Feng Shui location, land, interior design, and house number would influence the selling market.

\section{Conclusion}

House purchase may be an interesting experience despite the apprehension and uncertainties. Accordingly, the implementation of Feng Shui into the procedures of a house purchase is a proper method of investment. Furthermore, a positive feng shui indicates positive energy, which constantly appeals to individuals. In Feng Shui, the real estate notion of destination conveys meaning in more depth when it is associated with the standard of energy flowing into the house. Notably, the presence of positive energy within the house from its atmosphere is represented through the cleanliness of the street, good neighbours, absence of Sha Chi (elimination of energy) from nearby structures, and no slanted land at the back of the house among others. Several indications are present from this situation, which could assist the property developers and real estate agents in improving their understanding of the residential property buyers' perception of superstitious beliefs in the attempt of purchasing house. Moreover, developers who aim for the Chinese community are required to make prevention of the association between the hazard from the residential property projects and negative superstitions. For superstitions believers, various Feng Shui masters can conduct detailed analysis to determine the ideal house "gua". Despite the absence of belief among homebuyers regarding this matter, serious property investor would not be able to completely neglect it. Moreover, a savvy investor would acquire and implement some of these concepts into property buying which would assist in future house purchase. Lastly, the belief held by the homebuyer or superstitions believer regarding Feng Shui and its impact on their purchase decisions is their subjective decisions.

This research review the superstitious belief that exists in the real estate market which may or may not influence the housing purchase decision of the potential homebuyers especially in Malaysia. This demand is one of the most important topics to understand the behaviour of Malaysians buying houses in the Klang Valley. Not only the buyers but also the developers' belief in superstition. Living in Malaysia with so many races and cultures, Malaysians still believe in many superstitions, which is no stranger. Superstitious beliefs are believed to be passed on from ancestors to the next generation. This process continues until now, even if there is no scientific explanation, it is assumed that irrational beliefs are correct.

\section{Acknowledgements}

This research received full support from Universiti Putra M alaysia IPM Grant - Current Issues 9681400 (UPM RMC).

\section{References}

Bhatt, R. K. (2018, September 21). 5 Feng Shui Tips for Buying the Right House. This article is courtesy of Master Sandy Paw and was translated from Mandarin by Rachael Soh. 
Retrieved April 28, 2020 from https://www.iproperty.com.my/guides/5-feng-shui-tipsfor-buying-the-right-house/

Boyer, T. M. (1995). Instant Kiwis? A Study of the M igration and Adaptation of the Auckland Taiwanese Community, MA Thesis. Department of Geography, University of Auckland, New Zealand.

Buying a House with Best Feng Shui: M ind-blowing \& Proven Tips (2020, April 10). Retrieved April 28, 2020 from https://www.fengshuibalanz.com/fengshuitips/feng-shui-housebuying

Chong, T. T. L. \& Du, X. (2008). Hedonic pricing models for vehicles registration marks. Pacific Economic Review, 13(2), 259-276.

Chu, Y. C., Hsu, M. F., \& Hsieh, C. M. (2017). The Impacts of Site Selection and Planning of a Historic Settlement on a Sustainable Residence. Applied Ecology and Environmental Research, 15(2), 145-157.

Feng Shui for Your New Home: Joy Design \& Build. (2019, July 21). Retrieved April 28, 2020 from https://joycustom.com/blog/feng-shui-for-your-new-home/

Fortin, N. M ., Hill, A. J., Huang, J. (2014). Superstition in the Housing M arket. Economic Inquiry, 52(3), 974-993. doi:10.1111/ecin.12066

Fong, J., 2007. Feng Shui in The City: A Practical Handbook for Modern Urban Living. Shah Alam, Selangor Darul Ehsan: M arshall Cavendish.

He, X. X. (1995). The Source of Feng Shui. nTaipei: Yuan Bo Publishing Ltd. Press. 87-89

How Superstitions and Beliefs Can Affect the Malaysian Property Market (2019, December 17). Retrieved April 28, 2020 form https://insight.estate123.com/2016/08/16/howsuperstitions-and-beliefs-can-affect-the-malaysian-property-market/

Hui, K. M., Wai, C. W., \& Mei, N. S., (2019). The Effect of Superstitious Belief on Property Purchase Intention. International Journal of Real Estate Studies, 13(2)/2019, 1-13, ISSN 1832-8505.

Katie Avis-Riordan (2020, February 10). 13 Property Superstitions for Friday $13^{\text {th }}$. Retrieved $\begin{array}{llll}\text { April 28, } 2020 & \text { from }\end{array}$ https://www.housebeautiful.com/uk/lifestyle/property/news/a1195/house-sellingsuperstitions-friday-the-13th/

Kong, S.M . \& Chiong, L.C. (2006). Feng Shui and Buying House. JURUTERA, 20-27.

Liang, C. C., \& Osmadi, A. (2015). The Significance of Feng Shui in House Buying Selection among Malaysians. Jurnal Teknologi (Sciece \& Engineering), elSSN 2180-3722, 75:9, (2015) 15-19.

Mal Kong Sia, Vivien Wong Chin Yew \& Chee Lam Siew (2018). Influence of Feng Shui factors on house buying intention of M alaysian Chinese, Architectural Engineering and Design M anagement, 14:6, 427 439, DOI: 10.1080/17452007.2018.1466684

Marudawanan, R. (2018a, August 16). The Do's and Don'ts of Property Feng Shui. Retrieved April 28, 2020 from http://www.therooftalks.com/2018/08/16/your-property-fengshui-dos-and-dont/

Marudawanan, R. (2018b, October 22). Superstitions to Look Out For When Buying a Property. Retrieved April 28, 2020, from http://therooftalks.com/2018/10/22/propertysuperstitions-buying-property/ 
Propsocail Editor. (2016, April 22). Choosing Your Right Home the Feng Shui Way. Retrieved April 28, 2020 from https://www.propsocial.my/topic/559/choosing-your-right-homethe-feng-shui-way-posted-by-propsocial-editor

Rehm, M., Chen, S. \& Filippova, O. (2018). House prices and superstition among ethnic Chinese and non-Chinese homebuyers in Auckland, New Zealand. International Journal of Housing M arkets and Analysis, 11(1), 34-44.

Tam, C. M., Tso, T. Y. N., Lam, K. C. (1999). Feng Shui and its impacts on land and property development. Journal of Urban Planning and Development, 125(4), 152-163.

Tchi, R. (2013). Feng Shui History Part I: The Landscape School. Retrieved 12 January, 2013, from:http://fengshui.about.com/od/theoryhistory/qt/fshistory2.htm

Tchi, R. (n.d.). Key Principles of the Feng Shui Bagua (Energy Map). Retrieved April 28, 2020, from https://www.thespruce.com/your-feng-shui-bagua-guide-1275056

Too, L. (1997). Feng Shui Fundamentals: Wealth. Element Books, Rockport, M ass.

Wong, W. C., Abdullah, N. A. H., \& Lim H. E. (2017). The value of Chinese superstitions in $M$ alaysia: Evidence from car plate auctioning. The Singapore Economic Review.

Wu, W. Y., Yau, O. H. M., Lu, H. Y. (2012). Feng Shui Principles in Residential Housing Selection. Psychology and Marketing, 29(7), 502-518.

$X u, P$. (1997). Feng Shui as a clue: identifying the landform patterns of impact zones from the 2013 historic mountain floods in boulder and nearby areas, Colorado, USA. International Scientific Journal Environmental Science.

Yau, A. H. T. (2015). To be or not to be superstitious - That's the question. Procedia-Social and Behavioral Sciences, 208, 5-12.

5 Feng Shui Tips You Should Follow because They Actually Make A Lot Of Sense (2018, February 15). Retrieved April 28, 2020 from https://says.com/my/lifestyle/feng-shuitips-that-make-sense 